imperialism. I prefer to aid the Vietnamese people, as much as I can, in their struggles.

$$
\begin{aligned}
& \text { Yours faithfully, } \\
& \text { IAN G. MORGAN }
\end{aligned}
$$

Centre de Neurochimie,

11 Rue Humann,

67-Strasbourg

\section{Katchalsky Memorial}

SIR,-As scientists we deeply regret Aaron Katchalsky's death and, as friends of the Palestinian people, we fully reprobate the circumstances of that senseless murder. However, the creation of a memorial fellowship to the benefit of the Weizmann Institute is a political gesture which, in the present circumstances, is inadequate and even shocking.

There is no neutral science in a country at war, and this is particularly true for the Israelian state, whose military power is to a very large extent based on advanced technology and high-level scientific manpower. The Weizmann Institute, being the biggest scientific centre of Israel, necessarily plays a key role in that process, even if an important part of the work done there has no direct military purpose and if individuals working at Rehovot are political opponents of the Israelian government. The close links existing between Israelian military and scientific establishments were illustrated, we are sorry to say, by Aaron Katchalsky himself, who, according to Nature (237, $301 ; 1972)$, was also a leader of the former Hagannah (an anti-Palestinian military organization) and a leading member of the scientific branch of the Israelian army, playing, as you pointed out, "a prominent role in the military affairs" of that country.

These "military affairs" included massacres of the civil population at Deir Yassin and other places, resulted in the expulsion of the Palestinian people from their own country and, more recently, in military occupation and virtual annexation of territories of three neighbouring lands. Accordingly, we feel that it is rather inopportune, to say the least, to subsidize an official Israelian institution and to provide in that way important moral support to the Israelian government in the name of the international scientific community. Yours faithfully, MiChÈle Minet Pierre Thuriaux

Universität Bern,

Botanische Institute,

Institut für Allgemeine Mikrobiologie, CH-3013 Bern,

Altenbergrain 21

\section{Announcemenis}

\section{Miscellaneous}

ON Monday, July 31, the last seminar held under the auspices of the Institute of Theoretical Astronomy, Cambridge, will be given by $\mathrm{Dr}$ S. Aarseth. Its title is "Experimental Numerical Dynamics Is Only Time-dependent Approach".

\section{Reports und Publications}

not included in the Monthly Books Supplement

\section{Great Britain and Ireland}

Advisory Committee on Oil Pollution of the Sea. Annual Report for 1971. Pp, 20, (London: Fauna Preservation Society, c/o Zoological Society of ondon, 1972.)

Griffin and George, Laboratory Equipment Catalogue 72. Pp. 1073. (Wembley, Middx. : Griffin and George Limited, 1972.)
Department of the Environment. Thirteenth ProDepartment of the Environment. Thirteenth Pro-
gress Report of the Standing Technical Committee on Synthetic Detergents. Pp. iv +43 . (London: I66 Fabian Research Series, No. 302: Cuba's Educaional Revolution. By A 1972) 45p. 36 London: Fabian Society, 1972.) 45p. Economics and Management in Public Health Engineering. (Proceedings of the Fifth Public Health Civil Engineering, Loughborough University of TechCivil Engineering, Loughborough University of TechPp. 80. (Loughborough: University of Technology,
The Grassland Research Institute, Annual Report for 1971. Pp. 142. (Hurley, Maidenhead: The Grassland Research Institute, 1972) 11.50. [76
Department of Trade and Industry. Metrication Department of Trade and Industry. Metrication
Bibliography: Books and Pamphlets. Pp. 29. (St. Mary Cray, Orpington, Kent: Department of Trade and Industry, Technology Reports Centre, 1972.) 40p net. Robert Birley. Pp. 24. (Edinburgh: Heriot-Watt University Committee of WUS, 1972. Published for $30 \mathrm{p}$. 30p.ience Research Council. Space Research Reports, August 1969 to July 31 1970. Pp. 122.
(London: HMSO, 1972.) $£ 1.20$ net.

\section{Other Countries}

US Department of Commerce: National Oceanic and Atmospheric Administration. Atlantic Oceanographic and Meteorological Laboratories. Collected Vol. 2: Reprints Nos. 42-75. \$4.50. (Washington, DC: Government Printing Office, 1972.) [85
[8

US Department of the Interior: Geological Survcy. Professional Paper 394: Uppermost Precambrian and Lowest Cambrian Rocks in Southeastern Pp. iv $+52+$ plates $1-6$. $\$ 2.25$. Professional Paper 655-D: Geology and Ground-Water System in the Gila River Phreatophyte Project County, Arizona, By William G. Weist, Jr. Pp. iii +22 + plates 1-3. Professional Paper 726-B: Gravity and Magnetic Evidence of Lithology and Structure in the Gulf of Maine Region. By M. F. Pp, iii +22 t plates 1 and 2 . $\$ 1.25$. Washington. DC: Government Printing Office, 1971 and 1972.) [85 The Mechanization, Automation, and Increased Effectiveness of the Clinical Laboratory. (A Status Report by the Automation in the Medical LaboraInstitute of General Medical Sciences, National Institute of Health.) Pp. 78. (Washington, DC: Government Printing Office, 1972.) 70 cents. [95 Smithsonian Contributions to Paleobiology, No. 11: Homeomorphy in Recent Deep-Sea Brachiopods. By G. Arther Cooper. Pp. 23 (3 plates). 50 cents. Smithsonian Contributions to Zoology. No. 76: Proceedings of the First International Conference on Meiofauna. Edited by Neil $C$. Hulings. Pp. viii + 205. \$2.25. No. 105 : Origins and Affinities of the Troglobitic Crayfishes of North America (Decapoda: Astacidae). II. Genus Orconectes. By Horton H. Hobbs, Jr, and Thomas C. Barr, Jr. Pp. iii +84 . \$1.25. No. 115: Bredin-ArchboldSmithsonian Biological Survey of Dominica: Acueate Wasps (Hymenoptera: Scolloidea, Vespoidea, . p. All : The Genus Octrotrichta from Mexico and Centrol tilidac) By Oliver S. Flint, Jr. Pp. 28. H0 cents. Washing 1971 and 1972 . For sale by US Government Printing Office.)

US Department of the Interior: Geological Survey. Bulletin 1354-C: Big Sandy Formation near Wheppard and Arthur J. Gude, 3d. Pp. iiit 10. 15 Sheppard and Arthur J. Gude, ${ }^{3 d}$. Pp. iii + 10 . 15 cents. Water-Supply Paper 1899-M: Geohydrologic Louisiana. By Joseph W. Lang. Pp. iv $+44+$ plates 1 and 2. \$1. Professional Paper 724-B: Normal Fatty Acids in Estuarine and Tidal-Marsh Sediments of Choctawhatchee and Apalachee Bays, Northwest Florida. By Robert E. Miller. Pp. Iii 1. 13. 30 cents. (Washington, DC: Government Printing Office, 1972.)

\section{HOW TO BUY NATURE}

Volumes start in January, March, May, July, September and November, but subscriptions may begin at any time.

The direct postal price per subscription is:

12 MONTHS* (52 issues per title)

$\begin{array}{lcc} & \begin{array}{c}\text { Surface mail } \\ \text { UK and } \\ \text { worldwide }\end{array} & \begin{array}{c}\text { U.S.A. and } \\ \text { Canada }\end{array} \\ \begin{array}{l}\text { Nature (Friday) } \\ \text { Nature + }\end{array} & £ 4 & \$ 48 \\ \text { Nature Physical Science } & £ 24 & \$ 83 \\ \begin{array}{l}\text { Nature + } \\ \text { Nature New Biology }\end{array} & £ 24 & \$ 83 \\ \text { All three editions } & £ 29.50 & \$ 108 \\ \text { Annual Index } & £ 1 & \$ 3\end{array}$

* Rates for shorter periods pro rata (minimum three months) (Charge for delivery by air mail on application)
Editorial and Publishing Offices of NATURE

MACMILLAN JOURNALS LIMITED

4 LITTLE ESSEX STREET, LONDON WC2R 3LF

Telephone Number: $01-836$ 6633. Telegrams: Phusis London WC2R 3LF Telex: 262024

711 NATIONAL PRESS BUILDING

WASHINGTON DC 20004

Telephone Number: 202-737 2355. Telex: 64280

Subscription Department

MACMILLAN JOURNALS LIMITED

BRUNEL ROAD, BASINGSTOKE, HANTS

Telephone Number: Basingstoke 29242

American display advertisements

NATURE SCIENTIFIC PUBLICATIONS INC.

711 NATIONAL. PRESS BUILDING WASHINGTON DC 20004

All other advertisements

T. G. SCOTT \& SON, LIMITED

1 CLEMENT'S INN, LONDON WC2A 2ED

Telephone 01-242 6264/01-405 4743

Telegrams: Textualist London WC2A 2ED

Registered as a newspaper at the Post Office

Copyright (C) Macmillan Journais Limited, July 281972 